\title{
FITOREMEDIASI DENGAN WETLAND SYSTEM MENGGUNAKAN ECENG GONDOK (Eichhornia crassipes), GENJER (Limnocharis flava), DAN SEMANGGI (Marsilea crenata) UNTUK MENGOLAH AIR LIMBAH DOMESTIK
}

\section{PHYTOREMEDIATION BY WETLAND SYSTEM USING WATER HYACINTH (Eichhornia crassipes), GENJER (Limnocharis flava), AND CLOVER (Marsilea crenata) FOR DOMESTIC WASTE WATER TREATMENT}

\author{
Iin Inayatun Nadhifah*, Putri Fajarwati, Eka Sulistiyowati \\ Fakultas Sains dan Teknologi, UIN Sunan Kalijaga Yogyakarta, Jl. Marsda Adi Sucipto Yogyakarta 55281 \\ *Corresponding author: inayatunnadhifah@yahoo.com
}

Naskah Diterima: 14 Mei 2018; Direvisi: 05 September 2018; Disetujui: 28 November 2018

\begin{abstract}
Abstrak
Semakin banyaknya pemukiman yang dibangun di bantaran sungai di Yogyakarta membuat sungai tercemar limbah rumah tangga. Penelitian ini bertujuan untuk mengetahui efektivitas tanaman eceng gondok (Eichhornia crassipes), genjer (Limnocharis flava), dan semanggi (Marsilea crenata) sebagai fitoremediator dengan wetland system dalam pengolahan air limbah domestik. Tahap pelaksanaan penelitian fitoremediasi diawali dengan pengukuran parameter air limbah yaitu $\mathrm{pH}$, suhu, DO, BOD, dan TDS. Setelah itu, dilakukan aklimatisasi tanaman pada reaktor yang berisi air dan wetland selama 1 minggu. Terdapat empat perlakuan (P1, P2, P3, dan P4) yang digunakan, yaitu P1: air limbah + wetland (sebagai kontrol), P2: air limbah + wetland +1 eceng gondok, P3: air limbah + wetland +1 genjer, $\mathrm{P} 4$ : air limbah + wetland +1 semanggi. Terdapat $2 \mathrm{x}$ pengulangan selama masa retensi 12 hari, 2 variasi pengenceran yaitu $10 \mathrm{x}$ dan $100 \mathrm{x}$. Hasil penelitian menunjukkan bahwa tanaman genjer mampu meningkatkan kadar DO sebesar $50 \%$ dan menurunkan kadar BOD sebesar 78\%, serta tanaman semanggi mampu menurunkan kadar TDS sebesar $41,4 \%$. Angka ini mencerminkan bahwa penggunaan tanaman-tanaman tersebut memiliki potensi besar dalam membantu pemurnian air.
\end{abstract}

Kata kunci: Fitoremediasi; Limbah domestik; Wetland system

\begin{abstract}
The increasing number of settlements built along the river banks in Yogyakarta resulted in household waste entering the river. This study aims at determining the effectiveness of water hyacinth (Eichhornia crassipes), genjer (Limnocharis flava), and clover (Marsilea crenata) as phytoremediators, in a wetland system. Firstly, wastewater parameters such as $p H$, temperature, DO, BOD, and TDS are measured. After that, plants were acclimatized in the reactors containing water and substrate derived from a wetland for 7 days. There were four treatments applied in this research (P1, P2, P3, and P4), P1: wastewater + wetland (as control), P2: wastewater + wetland +1 water hyacinth, P3: wastewater + wetland +1 genjer, P4: wetland water + wetland +1 clover. Each treatment was replicated twice during the 12 days retention period, and 2 variations of dilution of 10x and 100x. The results indicated that genjer plant was capable of increasing the DO level by 50\% and lowering the BOD level by 78\%, and the clover plant was able to decrease the TDS level by $41.4 \%$. Those results reveal that the use of the plants has huge potential in helping water purification.
\end{abstract}

Keywords: Domestic wastewater; Phytoremediation; Wetland system

Permalink/DOI: http://dx.doi.org/10.15408/kauniyah.v12i1.7792 


\section{PENDAHULUAN}

Berdasarkan keadaan geografisnya, Provinsi Daerah Istimewa Yogyakarta (DIY) memiliki luas wilayah terkecil kedua di Indonesia. Luas wilayahnya hanya mencapai $3.185,80 \mathrm{~km}^{2}$ atau $0,17 \%$ dari seluruh wilayah daratan NKRI (Mutijo et al., 2016). Jumlah penduduknya mencapai 3.679.176 jiwa dengan kepadatan sebesar 1.174,3 tiap $\mathrm{km}^{2}$ pada tahun 2015. Kepadatan penduduk DIY menempati peringkat ke-4 terpadat dari seluruh daerah di Indonesia (Kementerian Kesehatan, 2015). Kepadatan jumlah penduduk tersebut berakibat pada padatnya pemukiman. Hal tersebut juga memicu adanya pembangunan pemukiman di bantaran sungai. Akibatnya, sungai menjadi tercemar karena dijadikan tempat pembuangan limbah rumah tangga.

Kandungan limbah pencemar air antara lain dapat berupa logam berat, bakteri fecal coliform, fosfat, sodium, nitrogen, virus, dan bakteri patogen yang dapat mengganggu kesehatan masyarakat dan memengaruhi ekosistem perairan (Botkin \& Edward, 2011). Kandungan bahan pencemar tersebut dalam kadar tertentu dapat dijadikan sebagai indikator kualitas air. Indikator kualitas air selain bahan pencemar adalah biological oxygen demand (BOD) dan dissolved oxygen (DO) (Cunningham \& Mary, 2010). BOD merupakan jumlah oksigen yang digunakan oleh dekomposer untuk memecah bahan organik dalam jumlah tertentu (Enger \& Bradley, 2009). DO merupakan kandungan oksigen terlarut dalam air yang mendukung kelangsungan hidup berbagai jenis organisme akuatik (Cunningham Mary, 2010).

Indikator lain dapat berupa total dissolved solid (TDS) dan total suspended solid (TSS). TDS merupakan ukuran zat organik maupun anorganik yang terlarut pada suatu perairan (Agustira et al., 2013). TSS merupakan padatan yang tersuspensi (tidak terlarut) dalam air. Padatan ini terdiri atas lumpur, pasir halus, serta jasad-jasad renik yang disebabkan oleh kikisan tanah atau erosi yang masuk ke dalam perairan (Alaert, 1994). Indikator-indikator penentu kualitas air tersebut memiliki nilai yang berbeda-beda dimana air dapat dikatakan tercemar atau tidak.

Air yang tercemar dapat dikurangi kadar bahan pencemarnya dengan salah satu teknik yang disebut dengan fitoremediasi. Fitoremediasi merupakan pemanfaatan tanaman dan asosiasinya dengan mikroorganisme untuk mengurangi, mendegradasi, ataupun mengisolasi bahan pencemar lingkungan (Favas et al., 2014). Adanya penggunaan tanaman menjadikan teknik fitoremediasi lebih ramah lingkungan dan mampu menambah estetika serta murah dan mudah diterapkan (Moosavi \& Mohamd, 2013).

Beberapa tanaman yang dapat digunakan sebagai agen fitoremediator antara lain Eichhornia crassipes (eceng gondok). Tanaman ini mampu tumbuh pada perairan tercemar dan mampu menghasilkan biomassa (Rai \& Singh, 2016), Limnocharis flava (genjer), dan Marsilea crenata (semanggi) yang mampu mendeteksi adanya logam $\mathrm{Pb}$ dan meng-akumulasinya (Nurhayati et al., 2015). Masing-masing tanaman memiliki kemampuan yang berbeda-beda dalam mengurangi tingkat pencemaran air, salah satunya adalah tanaman genjer, berdasarkan penelitian Kamarudzaman et al. (2011), tanaman ini mampu mengakumulasi nutrien $\left(\mathrm{HN}_{3}-\mathrm{N}\right.$ dan $\left.\mathrm{PO}_{4}-\mathrm{P}\right)$ dan logam berat ( $\mathrm{Fe}$ dan $\mathrm{Mn}$ ) dari polutan air paling optimal pada jaringan akar. Kemampuan tanaman-tanaman tersebut dibandingkan untuk mengetahui keefektifan masing-masing sebagai agen fitoremediator pada penelitian ini.

Fitoremediasi dapat dilakukan menggunakan sistem lahan basah (wetland system). Sistem wetland buatan ini merupakan bentuk tiruan dari proses penjernihan air yang terjadi di rawa, dimana tumbuhan air (Hydrophita) yang hidup di rawa tersebut memegang peranan penting dalam mengembalikan kualitas air (Mardianto et al., 2014).

\section{MATERIAL DAN METODE}

Penelitian ini dilakukan pada bulan Oktober-November 2016 di Laboratorium Terpadu UIN Sunan Kalijaga Yogyakarta. Alat yang digunakan dalam penelitian ini adalah 16 ember plastik berukuran diameter $40 \mathrm{~cm}$ dan tinggi $20 \mathrm{~cm}$, termometer, indikator $\mathrm{pH}$ universal, TDS meter, seperangkat alat titrasi DO, dan botol gelap, sedangkan bahan-bahan yang dibutuhkan yaitu air limbah rumah tangga dari Sungai Gajah Wong Yogyakarta, air, tanah sawah sebagai wetland yang diambil dari 
sawah daerah Nologaten-Sleman-Yogyakarta, tanaman eceng gondok, semanggi, dan genjer.

\section{Rancangan Percobaan}

Percobaan dilakukan menggunakan simpel random desain, dengan total keseluruhan rancangan penelitian dengan 4 perlakuan, 2 variasi pengenceran, dan 2 waktu pengukuran. Pada penelitian ini diterapkan 4 perlakuan, perlakuan I (air limbah + wetland), perlakuan II (air limbah + wetland +1 eceng gondok), perlakuan III (air limbah + wetland +1 genjer), dan perlakuan IV (air limbah + wetland +1 semanggi). Perlakuan I digunakan sebagai kontrol, karena tidak ada treatment fitoremediasi. Penentuan jumlah tanaman pada setiap perlakuan didasarkan pada jurnal dari Taner dan Vivian (1997) yang menyatakan bahwa kerapatan tanaman untuk perlakuan wetland adalah 4 tanaman tiap meter persegi. Reaktor yang akan digunakan berukuran luas $0,23 \mathrm{~m}^{2}$, sehingga jumlah tanaman yang digunakan sebanyak 1 tanaman. Penentuan 1 tanaman berdasarkan kelengkapan bagian tubuhnya. Tanaman yang dipilih merupakan tanaman yang lengkap bagian tubuhnya, yaitu terdapat akar, batang, dan daun. Tanaman yang digunakan hanya diambil 1 roset akar yang bagian tubuhnya lengkap. Pengenceran yang dilakukan dibuat 2 variasi, yaitu pengenceran 10x dan 100x. Pengenceran 10x artinya $11 \mathrm{~mL}$ sampel air limbah diencerkan dengan $99 \mathrm{~mL}$ air pengencer. Sedangkan untuk pengenceran 100x, hasil dari pengenceran 10x tersebut diambil $11 \mathrm{~mL}$ kemudian diencerkan kembali dengan $99 \mathrm{~mL}$ air pengencer $(\mathrm{HACH}$ Company, 2007). Untuk masa retensi dilakukan selama 12 hari dengan waktu pengukuran parameter $2 x$ yaitu pada hari ke- 6 dan ke-12. Penentuan masa retensi didasarkan pada penelitian Syuhaida et al. (2014) yang menyatakan bahwa waktu normal untuk mengetahui efek akumulasi polutan terhadap tanaman pada treatment fitoremediasi yaitu 10 hari. Sedangkan waktu pengukuran pada hari ke-6 didasari dari hasil penelitian Sitompul et al. (2013) yang menyatakan bahwa tanaman eceng gondok efektif untuk mengolah air limbah dengan waktu kontak 6 hari.

\section{Aklimatisasi}

Tanaman eceng gondok, genjer, dan semanggi yang diambil dari lingkungan di daerah Banguntapan-Bantul-Yogyakarta dipilih yang seragam ukurannya, dibersihkan dari kotoran yang menempel di akarnya. Kemudian, tanaman diaklimatisasi dengan cara ditanam pada reaktor dari ember yang berisi air dan wetland. Tanaman masing-masing diaklimatisasi selama 1 minggu dan diamati pertumbuhannya (Ratnani et al., 2010).

\section{Pengukuran Parameter Air Limbah}

Air limbah yang diukur berasal dari dua outlet yang berbeda. Limbah yang diambil dari outlet A disebut limbah A dan yang diambil dari outlet B disebut limbah B. Keduanya sama-sama merupakan air limbah rumah tangga. Perbedaannya hanya terletak pada sumber air limbah tersebut berasal. Keduanya diambil dari dua sumber pembuangan limbah berbeda yang sama-sama dialirkan ke sungai Gajah Wong Yogyakarta. Pengambilannya dilakukan dalam waktu yang sama, yaitu pagi hari. Setelah itu masing-masing limbah baik dari outlet A maupun outlet B diukur parameter $\mathrm{pH}$ menggunakan indikator $\mathrm{pH}$ universal, suhu menggunakan termometer, TDS menggunakan TDS meter, serta DO dan BOD menggunakan metode titrasi Mikro Winkler (APHA, 1999).

Suhu diukur dengan menggunakan termometer air. Termometer dicelupkan ke dalam air limbah pada masing-masing bak perlakuan dan kontrol sampai diketahui suhunya. Kemudian hasilnya dicatat. $\mathrm{pH}$ diukur dengan menggunakan indikator $\mathrm{pH}$ universal.

Pengukuran DO dilakukan dengan metode Micro Winkler menurut Silalahi (2010). Prinsip pengukuran BOD yaitu mengukur kandungan oksigen terlarut awal (DOi) dari sampel segera setelah pengambilan contoh, kemudian meng-ukur kandungan oksigen terlarut pada sampel yang telah diinkubasi selama 5 hari pada kondisi gelap dan suhu tetap $\left(20{ }^{\circ} \mathrm{C}\right)$ yang disebut dengan D05. Selisih DOi dan DO5 (DOi-DO5) merupakan nilai BOD yang dinyatakan dalam miligram oksigen per liter (mg/L) (Agustira et $a l .$, 2013). Satuan $\mathrm{mg} / \mathrm{L}$ bisa juga dinyatakan dalam part per million (ppm) karena memiliki nilai yang sama (Boguski, 2006). Pengukuran TDS dilakukan menggunakan alat TDS meter. 


\section{Analisis Data}

Teknik analisis data yang digunakan adalah secara deskriptif. Data hasil pengukuran parameter dibandingkan dengan parameter baku mutu air limbah cair domestik sesuai Keputusan Menteri Negara No. 82 tahun 2001 tentang baku mutu air limbah domestik dan Peraturan Daerah Kota Yogyakarta No. 7 tahun 2016 tentang baku mutu air limbah. Efektivitas tanaman dapat diketahui melalui data yang dihasilkan dari pengukuran parameter air limbah setelah dilakukan treatment fitoremediasi. Tanaman yang paling efektif adalah tanaman yang mampu menurunkan kadar TDS, meningkatkan kadar DO, dan menurunkan kadar BOD paling tinggi dibandingkan tanaman lain.

\section{HASIL}

Penelitian fitoremediasi dengan wetland system dilakukan untuk mengolah air limbah domestik dari perumahan di bantaran Sungai Gajah Wong Yogyakarta menggunakan tanaman genjer, eceng gondok, dan semanggi. Pengukuran parameter limbah tersebut dilakukan sebelum dan setelah dilakukan treatment fitoremediasi. Hasil pengukuran parameter dapat dilihat pada Tabel 1 .

Hasil pengukuran parameter air limbah domestik pada Tabel 1 selanjutnya dijadikan acuan untuk mengetahui kualitas air limbah setelah melalui proses fitoremediasi wetland system dengan masa retensi selama 12 hari. Air limbah yang digunakan dalam fitoremediasi dengan wetland system merupakan air limbah campuran limbah A dan limbah B dengan perbandingan 1:1. Sehingga, yang dijadikan acuan adalah parameter campuran dari limbah A dan B. Berikut ini merupakan hasil pengukuran parameter limbah dengan 8 perlakuan fitoremediasi dengan wetland system pada hari ke-12:

\section{Dissolved Oxygen (DO)}

Setelah

dilakukan

treatment fitoremediasi selama 12 hari, terjadi peningkatan kadar DO dari kisaran 2-3 ppm sebelum perlakuan (Tabel 1) menjadi kisaran 3-5 ppm setelah perlakuan (Gambar 1). Peningkatan DO tertinggi terdapat pada perlakuan air limbah dengan pengenceran 100x menggunakan genjer sebagai agen fitoremediator. Peningkat-an DO tersebut mencapai 2,5 ppm (50\%), dari sebelum perlakuan sebesar 2,5 ppm (Tabel 1) menjadi 5 ppm setelah perlakuan. Perlakuan dengan genjer untuk air limbah pengenceran 10x juga mengalami peningkatan dari $2,5 \mathrm{ppm}$ menjadi 4,6 ppm. Peningkatan tersebut masih lebih tinggi dibandingkan perlakuan meng-gunakan tanaman semanggi $(4,4$ ppm pada pengenceran $10 \mathrm{x})$ dan eceng gondok (4,4 ppm pada pengenceran 100x).

\section{Biological Oxygen Demand (BOD)}

Penurunan BOD tertinggi terdapat pada perlakuan limbah cair pengenceran 10x dengan tanaman genjer sebagai agen fitoremediator. Kadar penurunan BOD pada perlakuan tersebut mencapai 5,5 ppm yaitu dari kadar awal 7 ppm (Tabel 1) menjadi 1,5 ppm pada perlakuan hari ke-12 (Gambar 2).

\section{Total Dissolved Solid (TDS)}

Kadar TDS terendah terdapat pada kontrol pengenceran 10x dengan penurunan sebesar $171 \mathrm{ppm}$. Perlakuan fitoremediasi menggunakan tanaman semanggi pengenceran 100x juga menunjukkan penurunan kadar TDS lebih besar dibandingkan perlakuan yang lain, walaupun masih lebih rendah dibandingkan kontrol (Gambar 3). Penurunan kadar TDS tersebut sebesar 164,5 ppm $(41,4 \%)$ dari kadar awal 397,5 ppm (Tabel 1) menjadi 233 ppm setelah perlakuan fitoremediasi dengan wetland system.

\section{Suhu}

Hasil penelitian menunjukkan bahwa perubahan suhu sebelum perlakuan (Tabel 1) dan setelah perlakuan (Gambar 4) masih dalam rentang normal, yaitu antara $28-29{ }^{\circ} \mathrm{C}$. Rentang suhu tersebut juga berlaku untuk air tawar.

\section{pH}

Hasil pengukuran $\mathrm{pH}$ pada hari ke-12 dari semua perlakuan limbah menggunakan genjer, eceng gondok, semanggi, maupun kontrol dengan variasi pengenceran 10x dan 100x menunjukkan nilai 7. Hasil tersebut menunjukkan tingkat penurunan yang konstan, yaitu dari $\mathrm{pH}$ sebelum perlakuan sebesar 8 (Tabel 1) menjadi 7 setelah perlakuan. 
Tabel 1. Karakteristik awal air limbah domestik dari perumahan di bantaran Sungai Gajah Wong Yogyakarta sebelum dilakukan treatment

\begin{tabular}{lccccc}
\hline \multicolumn{1}{c}{ Limbah } & $\mathrm{pH}$ & Suhu $(\mathrm{C})$ & Parameter & \\
& 8,00 & 29,10 & 405,00 & 3,00 & 10,00 \\
$\mathrm{~A}$ & 8,00 & 29,00 & 390,00 & 2,00 & 4,00 \\
$\mathrm{~B}$ & 8,00 & 29,05 & 397,50 & 2,50 & 7,00 \\
Campuran A \& B &
\end{tabular}

Keterangan: Limbah A: air limbah domestik dari outlet A; Limbah B: air limbah domestik dari outlet B

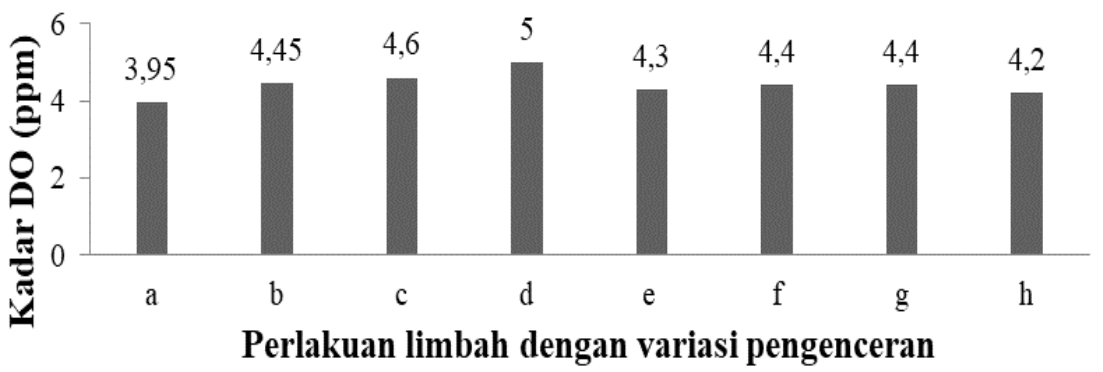

Gambar 1. Kadar DO treatment fitoremediasi limbah cair domestik dari perumahan di bantaran Sungai Gajah Wong Yogyakarta pada hari ke-12

Keterangan perlakuan limbah dengan variasi pengenceran: a. kontrol (10x), b. kontrol $(100 x)$, c. genjer (10x), d. genjer (100x), e. eceng gondok (10x), f. eceng gondok (100x), g. semanggi (10x), h. semanggi (100x)

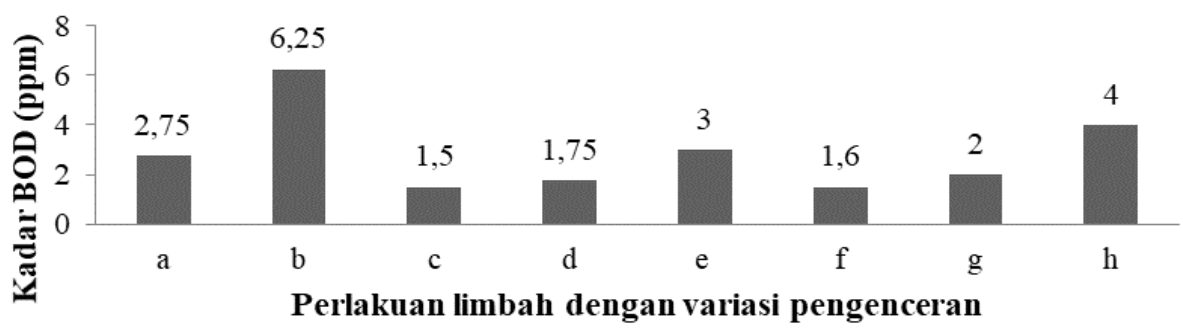

Gambar 2. Kadar BOD treatment fitoremediasi limbah cair domestik dari perumahan di bantaran Sungai Gajah Wong Yogyakarta pada hari ke-12

Keterangan perlakuan limbah dengan variasi pengenceran: a. kontrol (10x), b. kontrol $(100 x)$, c. genjer (10x), d. genjer (100x), e. eceng gondok (10x), f. eceng gondok (100x), g. semanggi (10x), h. semanggi (100x)

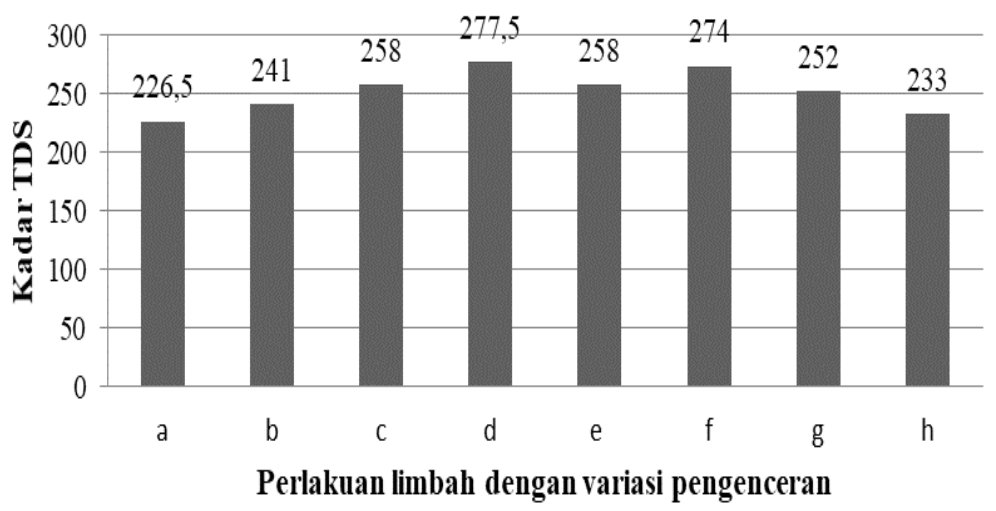

Gambar 3. Kadar TDS treatment fitoremediasi limbah cair domestik dari perumahan di bantaran Sungai Gajah Wong Yogyakarta pada hari ke-12

Keterangan perlakuan limbah dengan variasi pengenceran: a. kontrol (10x), b. kontrol $(100 x)$, c. genjer (10x), d. genjer (100x), e. eceng gondok (10x), f. eceng gondok (100x), g. semanggi (10x), h. semanggi (100x). Pengenceran 100x pada semanggi memiliki kadar TDS lebih rendah daripada pengenceran $10 \mathrm{x}$, berbeda dengan perlakuan lainnya 


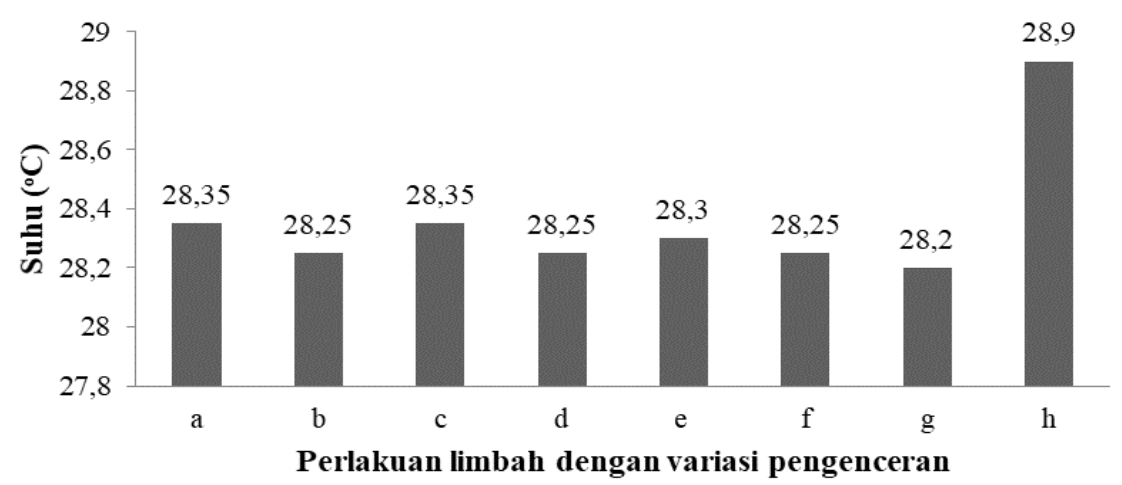

Gambar 4. Kadar suhu treatment fitoremediasi limbah cair domestik pada hari ke-12

Keterangan perlakuan limbah dengan variasi pengenceran: a. kontrol (10x), b. kontrol $(100 x)$, c. genjer (10x), d. genjer (100x), e. eceng gondok (10x), f. eceng gondok (100x), g. semanggi (10x), h. semanggi (100x)

\section{PEMBAHASAN}

Menurut Etim (2012), fitoremediasi sudah ada sejak 1991 untuk menjelaskan kegunaan tanaman dalam mengurangi volume, mobilitas, maupun toksisitas dari kontaminan dalam tanah, air tanah, maupun media lainnya. Hasil fitoremediasi yang peneliti lakukan diketahui dengan membandingkan hasil pengukuran parameter air sebelum treatment dan setelah treatment. Hasil yang disajikan dalam Tabel 1, menunjukkan $\mathrm{pH}$ dengan nilai 8 yang berarti air limbah domestik cenderung basa. Menurut Wirawan et al. (2014), nilai $\mathrm{pH}$ yang cenderung basa dapat disebabkan masuknya zat yang bersifat basa yang berasal dari sabun, shampoo, maupun deterjen. Hal ini karena sampel air limbah yang diukur berasal dari outlet rumah warga yang memang dalam aktifitas sehari-hari tidak terlepas dari penggunaan sabun, shampoo, dan deterjen. $\mathrm{pH}$ merupakan ukuran keasaman ataupun alkalinitas suatu perairan (Stephanie, 2012). $\mathrm{pH}$ pada suatu perairan dipengaruhi oleh aktivitas fotosintesis tumbuhan air, suhu, dan salinitas (Azis, 2013).

Hasil pengukuran parameter suhu menunjukkan bahwa suhu air limbah sebesar $29,1{ }^{\circ} \mathrm{C}$ dan $29{ }^{\circ} \mathrm{C}$ masih dalam kisaran normal. Suhu air limbah tersebut dipengaruhi oleh sinar matahari, karena waktu pengambilan sampel sekitar jam 8-10 pagi dimana intensitas cahaya matahari pada jam-jam tersebut mulai meningkat (Wijayanto \& Nurunnajah, 2012). Setelah dilakukan treatment fitoremediasi selama 12 hari, terjadi perubahan suhu, yang masih dalam rentang normal juga yaitu antara 28-29 ${ }^{\circ} \mathrm{C}$ (Gambar 4). Menurut Patty (2013), suhu normal air di perairan Indonesia pada umumnya berkisar antara $28-31{ }^{\circ} \mathrm{C}$. Rentang suhu tersebut juga berlaku untuk air tawar. Berdasarkan hasil penelitian Irwan et al. (2017) suhu yang berkisar antara $26-31{ }^{\circ} \mathrm{C}$ masih tergolong normal dan tidak membahayakan kehidupan biota akuatik karena masih di bawah lethal temperature (35$\left.40{ }^{\circ} \mathrm{C}\right)$.

Pengukuran TDS pada limbah A menghasilkan nilai sebesar $405 \mathrm{ppm}$ dan limbah B sebesar 390 ppm. Secara umum, TDS merupakan garam inorganik, zat-zat organik, dan material lain yang terlarut di dalam air (Scannell \& Laura, 2001). Standar nilai TDS untuk air tawar adalah 100-1000 ppm (Stephanie, 2012). Sehingga hasil pengukuran menunjukkan nilai normal. Setelah dilakukan treatment fitoremediasi selama 12 hari, hasilnya menunjukkan bahwa terjadi penurunan kadar TDS pada setiap perlakuan (Gambar 3).

Kadar oksigen terlarut juga sangat memengaruhi kehidupan organisme akuatik. Hasil pengukuran DO pada limbah A dan limbah B tidak berbeda jauh. Limbah A memiliki kadar DO sebesar 3 ppm dan limbah B sebesar $2 \mathrm{ppm}$. Setelah dilakukan treatment fitoremediasi selama 12 hari, terjadi peningkatan kadar DO dari kisaran 2-3 ppm sebelum perlakuan (Tabel 1) menjadi kisaran 3-5 ppm setelah perlakuan. Berdasarkan hasil penelitian di atas, peningkatan tersebut menunjukan perubahan status kualitas air dari tercemar sedang menjadi tercemar ringan (Gambar 1) (Silalahi, 2010).

Parameter selanjutnya yang diukur setelah parameter $\mathrm{DO}$ adalah $\mathrm{BOD}_{5}$. Hasil 
pengukuran $\mathrm{BOD}_{5}$ untuk limbah A sebesar 10 ppm, sangat berbeda jauh dengan limbah B sebesar 4 ppm (Tabel 1). BOD diartikan sebagai banyaknya oksigen yang dibutuhkan oleh mikroorganisme untuk memecah bahan organik dalam kondisi aerobik (Salmin, 2005). Seperti halnya hasil pengukuran DO, berdasarkan status kualitas air, hasil pengukuran BOD limbah awal sebelum perlakuan (Tabel 1) tergolong tercemar sedang. Status kualitas air tersebut yaitu BOD $\geq 15$ ppm tergolong tercemar berat; 5,1-14,9 ppm tercemar sedang; 3,0-5,0 ppm tercemar ringan; dan $\mathrm{BOD} \leq 2,9 \mathrm{ppm}$ tidak tercemar (Silalahi, 2010). Hasil penelitian menunjukkan bahwa nilai BOD mengalami penurunan setelah perlakuan fitoremediasi dengan wetland system selama 12 hari (Gambar 2). Penurunan BOD tersebut menunjukkan perubahan status kualitas air dari tercemar sedang menjadi tercemar ringan, kecuali kontrol dengan pengenceran $100 \mathrm{x} \quad(6,25 \mathrm{ppm})$ masih menunjukkan tercemar sedang.

\section{SIMPULAN}

Tanaman Limnocharis flava (genjer), Eichhornia crassipes (eceng gondok), Marsilea crenata (semanggi) efektif sebagai agen fitoremediator dengan wetland system dalam pengolahan air limbah domestik. Namun, keefektifan ketiga tanaman tersebut berbeda-beda. Tanaman genjer mampu meningkatkan kadar DO sebesar 50\% dan menurunkan kadar BOD sebesar 78\%. Sedangkan tanaman semanggi lebih efektif dalam menurunkan kadar TDS yaitu sebesar $41,4 \%$.

\section{REFERENSI}

Agustira, R., Lubis, K. S., \& Jamilah. (2013). Kajian karekteristik kimia air, fisika air dan debit sungai pada kawasan DAS Padang akibat pembuangan limbah tapioka. Jurnal Online Agroteknologi, 1(3), 617-618.

Alaert, S. S. S. (1994). Metoda penelitian air. Surabaya: Penerbit Usaha Nasional.

APHA. (1999). Standard methods for the examination of water and wastewater. America: American Public Health Association, American Water Works Association, Water Environment Federation.
Azis, H. (2013). Analisis kualitas perairan untuk pemanfaatan Pantai Boe sebagai tempat wisata pemandian pada musim barat di Desa Mappakalompo Kecamatan Galesong Kabupaten Takalar (Skripsi). Jurusan Ilmu Kelautan, Universitas Hasanuddin, Makassar.

Boguski, T. K. (2006). Understanding units of measurement. (2006, October). Retrieved from https://cfpub.epa.gov.

Botkin, D. B., \& Edward, A. K. (2011). Environmental science, earth as a living planet. United State of America: John Wiley and Sons, Inc.

Cunningham, W., \& Mary, C. (2010). Principle of environmental science. New York: The McGraw-Hill Companies.

Enger, E. D., \& Bradley, F. S. (2009). Environmental science, a study of interrelationships. New York: The McGraw-Hill Companies.

Etim, E. E. (2012). Phytoremediation and its mechanisms: a review. International Journal of Environment and Bioenergy, 2(3), 120-136.

Favas, P. J. C., Joao, P., Mayank, V., Rohan, D., \& Manoj, S. P. (2014). Phytoremediation of soils contaminated with metals and metalloids at mining areas: potential of native flora. (2014). Retrieved from http://creative commons.org/licenses/by/3.0.

HACH Company. (2007). MPN dilutions guidelines, serial dilutions method. USA: Hach Company/ Hach Lange GmbH.

Kamarudzaman, A. N., Mohd, A. H. Z., Roslaili, A. A., \& Mohd, F. A. J. (2011). Study the accumulation of nutrients and heavy metals in the plant tissues of Limnocharis flava planted in both vertical and horizontal subsurface flow constructed wetland. In (Ed.), . International Conference on Environment and Industrial Innovation IPCBEE Vo.12. Singapore.

Irwan, M., Alianto., \& Yori, T. T. (2017). Kondisi fisik kimia air sungai yang bermuara di Teluk Sawaibu Kabupaten Manokwari. Jurnal Sumberdaya Akuatik Indopasifik, 1(1), 86. 
Kementerian Kesehatan. (2015). Ringkasan eksekutif data dan informasi kesehatan Provinsi Daerah Istimewa Yogyakarta. Yogyakarta: Kementerian Kesehatan.

Mardianto, W., Apriani, I., \& Hayati, R. (2014). Pengolahan limbah cair rumah makan menggunakan sistem kombinasi ABR dan wetland dengan sistem kontinu. Jurnal Mahasiswa Teknik Lingkungan UNTAN, 1(1), 3 .

Moosavi, S. G., \& Mohamd, J. S. (2013). Phytoremediation: a review. Journal Advance in Agriculture and Biology, $1(1), 5-11$.

Mutijo., Kusriatmi., Suryono., Gita, O., Fitri, P. A., \& Nurita. (2016). Analisis informasi statistik pembangunan Daerah Istimewa Yogyakarta. Yogyakarta: Badan Perencanaan Pembangunan Daerah-Badan Pusat Statistik Daerah Istimewa Yogyakarta.

Nurhayati, A. Y., Hariadi, Y. C., \& Lestari, P. (2015). Early detection of lead stress on Marsilea crenata using biolectricity measurement. Elsevier Procedia Environmental Sciences, 28(2015), 5766.

Patty, S. I. (2013). Distribusi suhu, salinitas dan oksigen terlarut di Perairan Kema, Sulawesi Utara. Jurnal Ilmiah Platax, 1(3), 150 .

Rai, P. K., \& Singh, M. M. (2016). Eichhornia crassipes as a potential phytoremediation agent and an important biosource for Asia Pasific Region. Article of Environmental Skeptics and Critics, 5(1), 12-19.

Ratnani, R. D., Indah, H., \& Laili, K. (2010). Pemanfaatan eceng gondok (Eichornia crassipes) untuk menurunkan kandungan COD (chemical oxygen demand), $\mathrm{pH}$, bau, dan warna pada limbah cair tahu (Laporan Penelitian Terapan). Fakultas Teknik, Universitas Wahid Hasyim, Semarang.

Salmin. (2005). Oksigen terlarut (DO) dan kebutuhan okigen biologi (BOD) sebagai salah satu indikator untuk menentukan kualitas perairan. Jurnal Oseana (Majalah Ilmiah Semi Populer), XX(3), 21-26.
Scannell, P. W., \& Laura, L. J. (2001). Effects of total dissolved solids on aquatic organisms. Alaska: Alaska Department of Fish and Game Restoration.

Silalahi, J. (2010). Analisis kualitas air dan hubunganya dengan keanekaragaman vegetasi akuatik di Perairan Balige Danau Toba (Pascasarjana Tesis). Fakultas Matematika dan Ilmu Pengetahuan Alam, Sekolah Pasca Sarjana Universitas Sumatera Utara, Medan.

Sitompul, D. F., Mumu, S., \& Kancitra, P. (2013). Pengolahan limbah cair Hotel Aston Braga City Walk dengan proses fitoremediasi menggunakan tumbuhan eceng gondok. Jurnal Institut Teknologi Nasional, 1(2), 10.

Stephanie. (2012). Water quality parameters and indicators. New South Wales: Namoi Catchment Management Authority, Water Watch New South Wales.

Syuhaida, A. W. A., Norkhotijah, S. I. S., Pravena, S. M., \& Awang, S. (2014). The comparison of phytoremediation abilities of water mimosa and water hyacinth. ARPN Journal of Science and Technology, 4(12), 728. ISSN: 22257217.

Taner, C. C., \& Vivian, C. K. (1997). Guidelines for constructed wetland treatment of farm dairy wastewaters in New Zealand. NIWA Science and Technology Series, (48), 42.

Wijayanto, N., \& Nurunnajah. (2012). Intensitas cahaya, suhu, kelambaban, dan perakaran lateral mahoni (Swietenia macrophylla King.) di RPH Babakan Madang, BKPH Bogor, KPH Bogor. Jurnal Silvikultur Tropika, 03(01), 8-13.

Wirawan, W. A., Ruslan, W., \& Liliya, D. S. (2014). Pengolahan limbah cair domestik menggunakan tanaman kayu apu (Pistia stratiotes L.) dengan teknik tanam hidroponik sistem DFT (deep flow technique). Jurnal Sumber Daya Alam dan Lingkungan, 1(2), 68. 